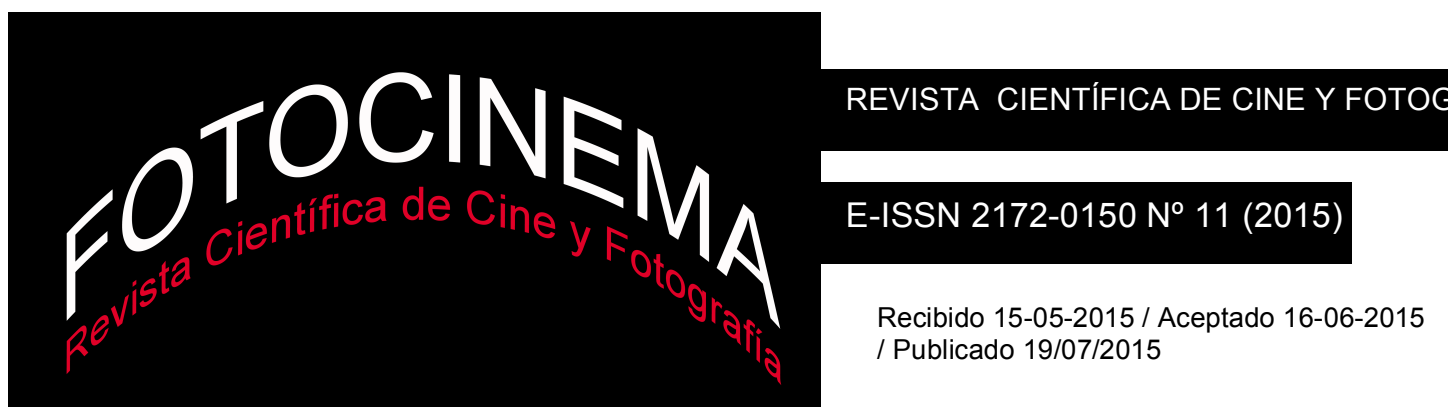

\title{
APORTACIONES HISTORIOGRÁFICAS Y ESTÉTICAS A PROPÓSITO DE LA CO-AUTORÍA FÍLMICA DE THE LAST OF THE MOHICANS (1920), DE MAURICE TOURNEUR Y CLARENCE L. BROWN
}

\section{HISTORIOGRAPHICAL AND AESTHETIC CONTRIBUTIONS TO THE FILMIC CO-AUTHORSHIP OF THE LAST OF THE MOHICANS (1920), DIRECTED BY MAURICE TOURNEUR AND CLARENCE L. BROWN}

Carmen Guiralt Gomar

Universidad de Valencia, España carmenguiralt@yahoo.es

\section{Resumen:}

El largometraje silente norteamericano The Last of the Mohicans (1920), sobre la famosa novela homónima de James Fenimore Cooper, se estrenó como codirigido por Maurice Tourneur y Clarence L. Brown. Tourneur era el productor y al inicio el único director, con Brown trabajando como su ayudante. No obstante, poco después de iniciarse la filmación cayó gravemente enfermo, y Brown realizó la película casi al completo en su lugar. De ahí que Tourneur decidiera otorgar a su discípulo la mitad del crédito. Pese a ello, la polémica al respecto de su autoría ha rodeado siempre al film. Tal controversia surge a raíz de que The Last of the Mohicans está considerada por unanimidad como la obra maestra de Tourneur. Este artículo se centra en dicha problemática autoral, con objeto de establecer las verdaderas atribuciones de los dos directores. Para ello, previamente se ha analizado su relación profesional, que abarcó desde 1915 hasta 1921. Con posterioridad, a fin de establecer el grado de participación de cada uno de ellos, se han reconstruido los hechos relativos al rodaje a través de entrevistas de los que participaron en él (muchas de ellas hasta la fecha inéditas), así como de materiales publicados por la prensa de la época. Se ha llevado a cabo la consulta y confrontación de abundante material bibliográfico y, finalmente, el análisis plástico de las imágenes de la cinta.

\begin{abstract}
:
The American silent film The Last of the Mohicans (1920), based on the famous homonymous novel by James Fenimore Cooper, was released as co-directed by Maurice Tourneur and Clarence L. Brown. Initially, Tourneur was the producer and the only director, with Brown being his assistant. However, shortly after shooting began he fell seriously ill. As a result, the film was almost entirely directed by Brown. Hence Tourneur decided to share the credit with his disciple. Still, the controversy concerning authorship has always surrounded the film. Such polemic arises from the fact that The Last of the Mohicans is considered unanimously Tourneur's masterpiece. This article focuses on that authorial problematic, with the aim of determining the real responsibilities of both directors. In order to achieve this objective, their professional relationship (which spans from 1915 to 1921) has been previously analysed. Subsequently, to establish the degree of participation of each of them, the facts of the shooting have been reconstructed using interviews (many of them unpublished) from those who took part in it, as well as through contemporary trade papers. In addition, research and confrontation on extensive bibliography have been carried out. Finally, the visual analysis of the images of the film has been evaluated.
\end{abstract}

\section{Palabras clave:}

Maurice Tourneur; Clarence Brown; Hollywood; Associated Producers, Inc.; cine mudo. Keywords:

Maurice Tourneur; Clarence Brown; Hollywood; Associated Producers, Inc.; Silent film. 


\section{Introducción}

La novela de James Fenimore Cooper The Last of the Mohicans (Boston, 1826; El último mohicano), sobre las guerras entre franceses e ingleses y sus distintas alianzas con los indios en su avance colonialista en el continente americano hacia 1757, ha sido llevada a la pantalla en multitud de ocasiones. De todas ellas, la versión silente de 1920 dirigida por Maurice Tourneur y Clarence L. Brown sigue estando considerada por los especialistas como la mejor y más fiel adaptación cinematográfica ${ }^{1}$.

$\mathrm{Su}$ reciente lanzamiento en formato DVD en nuestro país por parte de Classicmedia (Cinema International Media), “Colección Cine Mudo”, bajo el título de El último mohicano ${ }^{2}$ (junio, 2013), con la alteración del orden de presentación de sus dos co-directores en la carátula, proporciona el marco contextual idóneo para llevar a cabo un análisis a propósito de la controversia historiográfica relacionada con su co-autoría, una cuestión que ha rodeado al film desde la época de su estreno y a lo largo de las décadas hasta hoy. Especialmente porque, si bien hasta la fecha tanto las recensiones críticas coetáneas al largometraje como los textos historiográficos posteriores han tendido a oscurecer, menoscabar e incluso a obviar la contribución de su segundo co-director -Clarence L. Brown-, Classicmedia de manera inusitada ha realizado justo la operación contraria, anteponiéndole en la cabecera. Tendremos oportunidad de explicar el porqué de este cambio. Ahora bien, como demostraremos, ninguna de estas dos corrientes, ni la tradicional ni la efectuada por Classicmedia, se corresponde con la veracidad histórica del largometraje.

Este artículo se centra en la problemática de la autoría del film y tiene por objeto clarificar, desde el punto de vista historiográfico y desde la perspectiva del análisis de las imágenes, las competencias de cada uno de sus co-

\footnotetext{
${ }^{1}$ Sostienen esta opinión, por ejemplo, los siguientes autores: Slide, 1982, p. 650; Tavernier \& Coursodon, 1997, p. 372. Las versiones fílmicas sonoras más importantes de la novela son las de 1936 y 1992; la primera dirigida por George B. Seitz, con Randolph Scott; y la segunda realizada por Michael Mann, con Daniel Day-Lewis.

2 Aunque el largometraje original estadounidense no se estrenó en España, se ha popularizado y estrenado en DVD como El último mohicano, debido a la traducción de la novela.
} 
realizadores: Maurice Tourneur y Clarence L. Brown. Para ello, examinamos previamente los métodos de su asociación profesional, una singular relación de tutelaje del primero para con el segundo -totalmente infrecuente en el cine clásico norteamericano- que comenzó en 1915 y culminó en la codirección del film que nos ocupa, más una segunda y última película corealizada: The Foolish Matrons (1921). De forma simultánea, este trabajo supone una aproximación conjunta e individual a las figuras de ambos cineastas, quienes fueron altamente reputados $\mathrm{y}$ valorados mientras estuvieron en activo y, transcurridas las décadas, han caído en el olvido.

\section{Marco teórico y metodología}

Por separado, las aproximaciones historiográficas hacia Maurice Tourneur y Clarence Brown son escasas. Mientras que su relación laboral en común jamás ha sido abordada por la bibliografía preexistente, más allá de los comentarios puntuales y breves que incluimos en este estudio.

Tanto en el caso de Tourneur como en el de Brown, los materiales bibliográficos, además de exiguos, datan ya de antiguo y han sido elaborados por el mismo núcleo de investigadores, todos ellos grandes especialistas de la cinematografía silente pertenecientes al ámbito anglosajón: Kevin Brownlow, William K. Everson, Jan-Christopher Horak y Richard Koszarski.

El presente trabajo se inscribe en el marco de las investigaciones que llevamos años realizando sobre ambos directores y ha contado con la generosa ayuda y suministro de material de Kevin Brownlow, quien nos ha facilitado desde su colección particular - The Kevin Brownlow Collection, Londres, R.U.- el conjunto de sus entrevistas inéditas a Clarence Brown (Brownlow, 1965; Brownlow, 1966; Brownlow \& Knox, 1969). Este valiosísimo material es el que ha permitido reconstruir la colaboración cinematográfica entre Tourneur y Brown, así como fijar numerosas 
cuestiones relativas a películas y fechas concretas, desconocidas hasta el momento. Por todo ello, este artículo está en deuda con él3.

A fin de contrastar y reasentar los hechos históricos, también se han utilizado documentos procedentes de publicaciones coétaneas a los films, tanto especializados como generalistas: Moving Picture World, Motion Picture News, Photoplay, Picturegoer, New York Times, etc. Asimismo, todos los textos principales divulgados sobre Tourneur y Brown han sido consultados.

Con objeto de esclarecer la autoría de The Last of the Mohicans, primero analizamos la unión profesional de Tourneur y Brown y su evolución. Después, situamos el film en su contexto histórico, profundizamos en el rodaje y pasamos a confrontar los distintos testimonios del equipo de filmación, así como los juicios de diferentes historiadores referentes al controvertido tema autoral. Finalmente, concluimos con el análisis de las imágenes del largometraje.

\section{Asociación profesional de Maurice Tourneur y Clarence L. Brown (1915-1921)}

\subsection{Primeros años en Fort Lee, New Jersey (1915-1918)}

La figura de Maurice Tourneur (1876-1961) como cineasta consta harto relegada por la historiografía fílmica, hasta el punto de que a día de hoy tan solo se le conoce (si es que eso ocurre) como el padre del también director Jacques Tourneur, quien, paradójicamente, aprendió el oficio como su ayudante a finales de los años 20.

No obstante, Tourneur fue uno de los grandes pictorialistas del cine silente norteamericano y uno de sus creadores más destacados en la década de 1910, a la altura de David W. Griffith e incluso, a partir de un determinado momento, superándole de forma considerable en cuanto a fama, prestigio y valoración crítica. De acuerdo con Richard Koszarski (2004, p. 242), en torno a 1918 “...su reputación como el artista más sensible de la pantalla estaba en

\footnotetext{
3 Nuestro agradecimiento también a The University of Tennessee, Knoxville, Tennessee, Special Collections Library, donde se ubica The Clarence Brown Collection, por habernos proporcionado abundantes textos de difícil acceso.
} 
su punto más alto. Ni siquiera D. W. Griffith fue considerado su igual en términos de efectos fotográficos, de 'delicadeza' temática e incorporación total del simbolismo, entonces una virtud artística extraordinariamente considerada...”. En efecto, sus películas eran altamente apreciadas por los críticos del periodo, quienes las calificaban de manera continuada de “pictóricas” y "poéticas”, y él consiguió granjearse esta excelente reputación al poco tiempo de su llegada a los Estados Unidos, hecho que tuvo lugar en mayo de $1914^{4}$.

Tras un extensa carrera en el ámbito de las Bellas Artes, la escena y el cine desarrollada en su Francia natal, Tourneur llegó a los Estados Unidos, en la mencionada fecha, delegado por la Société Française des Films et Cinématographes Éclair para encabezar la producción de la filial en Fort Lee, New Jersey. Sin embargo, una sucesión de fusiones entre diversas sociedades ligaron su contrato a Peerless Feature Producing Co., más conocida como Peerless Pictures.

Justo un año después, en mayo de 1915, Clarence Brown se aproximó a él en búsqueda de un trabajo en el cine. El bagaje de éste en nada se asemejaba al de Tourneur. Clarence L. Brown (1890-1987) - como todavía se haría llamar durante algún tiempo- nació circunstancialmente en Clinton, Massachusetts, aunque sus raíces eran sureñas. Durante su adolescencia la familia regresó al Sur, a Koxville, donde estudió en The University of Tennessee y se graduó con una doble Licenciatura en Ingeniería Mecánica y Eléctrica. Después pasó a trabajar como asesor y mecánico experto en varias fábricas de automóviles y allá por 1913, dedicado a la compra-venta, poseía su propio concesionario en Birmingham, Alabama - Brown Motor Car Co. Brown encontró a Tourneur cerca de los Peerless Studios 5 filmando los exteriores de The Cub (1915) y, aunque carecía de experiencia en el cine, se

\footnotetext{
4 Sobre el enorme prestigio adquirido por el director cuando tan solo había realizado tres películas norteamericanas, véase "Maurice Tourneur", 1914, p. 1242.

5 Las películas producidas en los Peerless Studios tenían como red de distribución única a World Film Corporation, causa por la cual los estudios también fueron conocidos como World-Peerless.
} 
las ingenió para que le contratara como segundo ayudante de dirección ${ }^{6}$. A partir de entonces, pasó a formar parte del equipo permanente de Tourneur; una unidad de filmación fija que, con él como director-productor, le seguía en todas sus películas y traslado por distintas empresas de filmación7. Los miembros destacados de este primer equipo, con la excepción de Brown, eran en su mayoría franceses, de nacimiento o de adopción: el cámara John van den Broek - presente hasta su muerte en 1918-, un holandés que había vivido en Francia, hablaba francés perfectamente y había trabajado a las órdenes de Étienne Arnaud en Éclair Film Co.; y el director artístico Ben Carré -hasta 1919-, un parisiense procedente de Gaumont que, pese a ser de los primeros en llegar a Fort Lee, en la temprana fecha de 1912, nunca consiguió hablar inglés con fluidez. A comienzos de 1916, se incorporó el ayudante de cámara norteamericano Charles J. van Enger.

Al poco, Clarence Brown se convirtió en la mano derecha de Tourneur y comenzó a asumir mayores responsabilidades en sus películas: primer ayudante de dirección, montador y director de la segunda unidad en exteriores.

Respecto de sus funciones como montador, en años posteriores Brown declaró que, tras observar a Tourneur en la sala de edición, enseguida sintió interés y curiosidad por dicho ejercicio:

...me metí en la cabeza que tenía que poder hacer eso. Y no llevaba con TOURNEUR más de un mes cuando empecé a montar sus películas y a escribir los rótulos. De modo que le relevé de ese [proceso] final del negocio por completo. Antes lo hacía él mismo -y su cámara (Brownlow, 1965, p. 3).

Sin embargo, la apreciación de un mes como el tiempo que le llevó convertirse en el montador de Tourneur parece del todo exagerada, pues él provenía del negocio de los automóviles y acababa de iniciarse en el cine.

\footnotetext{
${ }^{6}$ En realidad, Brown se incorporó a la postproducción de Trilby (1915), la película que Tourneur acababa de filmar y estaba editando, y al rodaje de The Cub, donde ejerció por primera vez como ayudante.

7 Hemos de señalar que el funcionamiento de Tourneur en los Estados Unidos -hasta 1924- con sus diferentes equipos de filmación difiere por completo de la subdivisión del modo de producción del cine norteamericano que se establece en: Bordwell, Staiger \& Thompson, 1997, pp. 129-154.
} 
Kevin Brownlow, con quien cotejamos la información, se mostró de acuerdo con nosotros y nos escribió:

Él dice "en un mes estaba montando sus películas”. Eso pudo haber sido una exageración. Hace cuarenta años yo me creía todo lo que me decían, y aunque Brown no era un inventor de historias como Howard Hawks, era un hombre del espectáculo y si necesitaba decir algo importante exageraba. (...) Por otro lado, él fue tan brillante condiscípulo, que me imagino que le llevaría muy poco tiempo aprender la técnica en que llegó a ser tan competente $^{8}$.

De hecho, en otras entrevistas Brown señaló el periodo de medio año. Por ejemplo, tras entrevistarle Hildy Crawford (1964, p. 11) transcribió: "En menos de seis meses Brown estaba cortando todas las películas así como poniendo los rótulos y dándose cuenta de que su entrenamiento como ingeniero le era de gran utilidad en este trabajo". Por lo tanto, en torno a los últimos meses de 1915 podemos considerarle de manera efectiva como el montador único de Tourneur.

Con relación a los cometidos de Brown a cargo de la dirección de la segunda unidad en exteriores, él recalcó en numerosas ocasiones que el director francés sentía un profundo rechazo a rodar en localizaciones, debido a que no podía controlar las condiciones atmosféricas y de iluminación como en el estudio. Por ello, muy pronto comenzó a enviarle a rodar grandes porciones de los films en espacios abiertos. A través de sus declaraciones sabemos que esta asignación se produjo en los primeros meses de 1916:

...después de haber estado con él [Tourneur] un año, dirigí la mayor parte de sus exteriores, él odiaba los exteriores y nosotros teníamos dos compañías, Charlie Van Enger era mi cámara, y John Van Den Broek era su cámara y yo siempre cortaba y montaba la película y los intertítulos (Brownlow \& Knox, 1969, p. 29).

En la misma entrevista no publicada dio mayores detalles sobre el funcionamiento del equipo: Tourneur y él intercambiaban el reparto; el director francés se quedaba en el estudio con su propio cámara -Van den

${ }^{8}$ Correspondencia personal con Kevin Brownlow. 14/10/2008. 
Broek; y él se marchaba con el suyo -Van Enger-, pudiendo estar fuera hasta una jornada completa:

...no era como ahora, sabes, cogíamos a todo nuestro equipo en un automóvil de siete plazas y una cámara y salíamos fuera y tomábamos imágenes durante todo el día. (...) me llevaba a un actor y camiones de 25 toneladas y a 100 trabajadores del estudio para hacer algunas escenas lejos del estudio durante un día... (Brownlow \& Knox, 1969, p. 29).

De este modo, Tourneur y él trabajaban como dos unidades y podían realizar una importante cantidad de películas al año; les llevaba unas cuatro semanas finalizar un largometraje. De ahí que Brown, como veremos, no se considerara simplemente ayudante o montador, sino co-director. En realidad, desde comienzos de 1916, era co-artífice de los films, aunque éstos continuaban estrenándose como dirigidos sólo por Maurice Tourneur.

En esta primera etapa en Fort Lee, Tourneur y Brown acometieron juntos gran número de cintas, incluyendo el gran éxito de Mary Pickford The Poor Little Rich Girl (Una pobre rica, 1917) y dos películas de vanguardia experimentales inscritas en el terreno de la fantasía: The Blue Bird (El pájaro azul, 1918) y Prunella (1918), enormemente laureadas por la crítica, pero que naufragaron de forma estrepitosa en taquilla.

Seguidamente, en un momento cuya fecha exacta se ignora, pero del que conocemos se produjo iniciado ya el rodaje de Prunella -film que, según Moving Picture World, entró en fase de producción la semana del 13 de enero de 1918 ("Miss Clark to Star", 1918, p. 396)-, Brown abandonó su oficio en el cine para ingresar en el Servicio Aéreo del Ejército de los Estados Unidos de América e incorporarse a la Primera Guerra Mundial (Brownlow, 1965, p. 4).

Entretanto, Tourneur, al amparo del magnate suministrador de película virgen Eastman Kodak Jules Brulatour, quien había sido su socio financiero desde hacía tiempo, inauguró su propia compañía de producción: Maurice Tourneur Productions, Inc. Permaneció en Fort Lee hasta mediados de noviembre de 1918, momento en que se desplazó a California para filmar 
durante los meses de invierno ("Tourneur's 'Woman", 1918; "Tourneur to Produce”, 1918). Aunque ésa era su intención original, nunca regresó.

\subsection{Traslado a Hollywood (1919-1921)}

$\mathrm{Al}$ abandonar el ejército, Brown primero viajó a Fort Lee para recuperar su antiguo trabajo junto a Tourneur, pero al llegar descubrió que éste se había trasladado a Hollywood (Garnett, 1996, p. 13). Partió entonces hacia la Costa Oeste y llegó allí el día de Nochebuena de 1918.

Se inició así una segunda etapa, previa a la co-dirección de The Last of the Mohicans, en la que Brown volvió a trabajar como ayudante, montador y responsable de la segunda unidad y en medio de la cual se produjo su debut en la realización. Fue su mentor el que posibilitó su lanzamiento, produciendo para él, a través de Maurice Tourneur Productions, Inc., y distribución de Metro Pictures Corp., The Great Redeemer (1920), film que, aunque dirigido por Brown, se estrenó bajo la supervisión de Maurice Tourneur y se rodó en Universal. El razonamiento de este último de por qué impulsó a su discípulo a la dirección era: "Si no permito al Sr. Brown hacer una película, me dejará. Y si le permito hacer una película, me dejará” (Brownlow, 1965, p. 7).

Después de su iniciación como cineasta, Brown continuó asistiendo a su maestro. "¿Qué supuso para su ego dirigir una película y después volver y trabajar como ayudante de Tourneur?", le preguntaron Brownlow y Knox (1969, p. 33). Y la respuesta de Brown fue contundente:

Habría hecho cualquier cosa por él, quiero decir [que] cualquier cosa que decía estaba bien para mí, pero yo era más que un ayudante, era co-director, en cada película que hice después y después, o incluso antes cuando rodaba exteriores... cuando estábamos en Fort Lee.

En efecto, se consideraba co-director - de ahí que con anterioridad hubiera inscrito su ocupación en el ejército como tal (Neely, 2008, p. 19)-, pues estaba convencido de que ése era el verdadero trabajo que había realizado para Tourneur desde hacía tiempo. Faltaba muy poco para que su posición se hiciera oficial. 


\section{The Last of the Mohicans (Maurice Tourneur y Clarence Brown, 1920)}

A finales de 1920, Tourneur abandonó el respaldo económico de Brulatour y se unió a una nueva distribuidora impulsada por Thomas H. Ince: Associated Producers, Inc., una decisión que acabó teniendo consecuencias desastrosas en su carrera.

Distribución y exhibición eran factores clave para asegurarse un lugar en el negocio y en esos momentos las principales productoras estaban ya prácticamente establecidas: Famous Players-Lasky Co., Loew's Metro Pictures Co. y Fox Film Co. Con el apoyo de Wall Street, éstas estaban incrementando cada vez más sus circuitos de distribución, nacionales e internacionales, y adquiriendo en propiedad gran número de salas. Verticalmente integradas, controlaban así las tres ramas del negocio: producción, distribución y exhibición. Hollywood se estaba organizando. Estaba teniendo lugar la transición al studio system, con la configuración definitiva, hacia el final de los años 20 y principios de los 30, de las ocho grandes compañías que impondrían su supremacía durante las dos décadas siguientes: majors -Paramount, MGM/Loew's, Warner Bros., Twentieth Century-Fox y RKO- y minors - Universal, Columbia y United Artists.

Para contrarrestar su avance, los independientes habían comenzado a crear sociedades: First National Exhibitors' Circuit, Inc., (1917) y United Artists (1919), fundada por Mary Pickford, Douglas Fairbanks, David W. Griffith y Charles Chaplin, fueron las más importantes. A imagen y semejanza de esta última nació, en diciembre de 1919, Associated Producers, Inc., constituida por siete productores: Thomas H. Ince, Allan Dwan, Mack Sennett, Marshall Neilan, George Loane Tucker, J. Parker Read, Jr., y Maurice Tourneur. Producían de manera independiente, a través de sus propias compañías, pero distribuían de forma conjunta. Además de Tourneur, Dwan, Sennett y Neilan eran productores-directores, mientras que el resto se dedicaba a la producción-supervisión. Su planteamiento era similar al de United Artists, pues ninguno de estos pioneros, supervivientes de la primera era del cine, estaba dispuesto a convertirse en asalariado de las pujantes sociedades verticalmente integradas. Pretendían ser sus propios jefes, preservar su 
integridad artística, obtener los beneficios directos de su trabajo y asegurar la distribución de sus películas. No fueron los únicos. Desde antes de la década de 1920, pero sobre todo durante su transcurso, la lucha de personalidades destacadas del cine que se negaban a someterse al sistema se tradujo en la formación continuada de productoras individuales que constituían la manifestación explícita de sus intentos desesperados por sobrevivir9. Ninguna lo logró. Todas tuvieron una corta vida y pronto fueron absorbidas por el studio system - a excepción de United Artists, pocas sobrepasaron los dos años. La bancarrota financiera de Associated Producers, Inc., se produciría en septiembre de 1921.

El pacto de Tourneur con la distribuidora consistía en la entrega de doce películas al año: cuatro serían dirigidas por él personalmente, mientras que sus ayudantes, Clarence Brown y John Gilbert, acometerían cuatro cada uno. En verdad, el director francés tan solo llegó a entregar dos, ambas codirigidas con Clarence Brown: The Last of the Mohicans y The Foolish Matrons. Gilbert dio más detalles sobre el convenio de Tourneur con Associated Producers, Inc., en la cuarta y última entrega de su autobiografía publicada por Photoplay: "Brown y yo estábamos recibiendo el mismo salario -250 dólares por semana. Bajo el nuevo acuerdo íbamos a ser ascendidos a cuatrocientos por semana, con un diez por ciento adicional de los beneficios de las doce películas" (Gilbert, 1928, p. 41). El 10\% adicional de los beneficios de los doce films respondía al compromiso según el cual, mientras Tourneur llevara a cabo las suyas, ambos continuarían asistiéndole.

\subsection{Rodaje y consideraciones historiográficas a propósito de la co- autoría}

La producción de The Last of the Mohicans (F1) comenzó a finales de agosto de 1920 y concluyó en los últimos días de octubre. Tuvo lugar en el complejo de Universal y con numerosos exteriores en Big Bear Lake y Yosemite Valley,

9 Por ejemplo: King Vidor Productions; Mayflower Photoplay Corp., de Raoul Walsh; DeMille Pictures; William S. Hart Co.; Frank Keenan Productions, Inc.; Harold Lloyd Co.; Norma Talmadge Productions; Anita Stewart Productions; Charles Ray Productions; Hayakawa Feature Play Co., de Sessue Hayakawa; Gloria Swanson Pictures Corporation, etc. 
ambos en California. El largometraje se inició con Tourneur como realizador y, según el pacto establecido, con Brown como ayudante de dirección, junto a Charles Dorian ${ }^{10}$.

Cuando apenas habían transcurrido dos semanas de rodaje, Tourneur se cayó de un andamio de madera en exteriores de Big Bear Lake y, gravemente herido, permaneció confinado en el hospital durante seis semanas (Brownlow \& Knox, 1969, p. 31) ${ }^{11}$. Brown tomó a su cargo la dirección y, de acuerdo con su testimonio, realizó el largometraje completo desde ese momento -filmó en solitario tres cuartas partes de la película (Eyman, 1978, p. 20). Otras fuentes indican que hacia el final Tourneur regresó y pudo fotografiar escenas de interior en el estudio desde su silla de ruedas (Koszarski, 1973, p. 27).

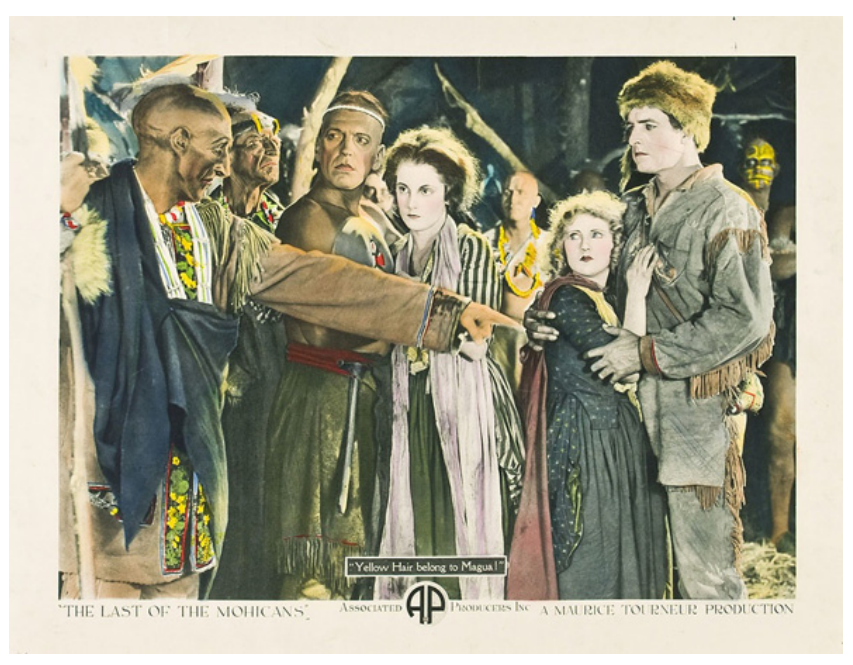

F1. Lobby card de The Last of the Mohicans.

Así pues, Tourneur ejerció como director único tan solo durante la última semana de agosto y la primera de septiembre de 1920. Brown rodó la película en solitario a lo largo de las seis semanas siguientes, mientras Tourneur

${ }^{10}$ John Gilbert no llegó a participar en el film, pues justo antes de que comenzara el rodaje fue contratado por Brulatour para llevar a cabo su primera película como director. Dorian era un extra al que Brown había conocido en Universal durante la filmación de The Great Redeemer, y al que, a pesar de que no tenía experiencia, le ofreció ser su ayudante - tal y como Tourneur había hecho con él cinco años atrás.

${ }^{11}$ En otras ocasiones, como se verá, Brown proporcionó la cifra, en apariencia exagerada e improbable, de tres meses como el tiempo que Tourneur estuvo ingresado en el hospital (Brownlow, 1965, p. 25). Por otra parte, él siempre insistió en que Tourneur se cayó (Brownlow, 1965, p. 25; Brownlow, 1968, p. 142; McGilligan \& Weiner, 1975-1976, p. 31; Eyman, 1978, p. 20). En cambio, la prensa de la época mencionó un envenenamiento por ptomaína (“Tourneur Ill”, 1920, p. 1134), razón por la que el dato figura en otros estudios posteriores (Geltzer, 1961, p. 202). 
estaba ingresado. Y el director francés, al parecer, se habría reincorporado a finales de octubre, en los últimos días de filmación.

Por esta causa, Tourneur, el productor y director del film, decidió otorgar por primera vez reconocimiento a su ayudante en los títulos de crédito. Con todo, existe una enorme polémica entre los especialistas sobre su autoría. Sin embargo, hemos de decir que ésta es una cuestión conjeturada casi en exclusiva por la historiografía y responde a una cuestión fundamental: The Last of the Mohicans está considerada por unanimidad como la mejor de las películas de Tourneur - su obra maestra ${ }^{12}$. Una auténtica paradoja, sin duda, pues se trata de una película perpetrada en su mayor parte por su ayudante.

Con relación a este tema, Anthony Slide (1982, p. 650) escribió: "Brown hizo un trabajo soberbio - probablemente mejor del que hubiera logrado Tourneur...”. Desde luego, el largometraje posee un ritmo narrativo, ágil y fluido, que no puede encontrarse en otras creaciones del director francés, cuya dramaturgia fílmica se había vuelto cada vez más lenta y parsimoniosa desde 1917. Al respecto de cómo queda emplazado este hecho en su filmografía, el autor continuó diciendo:

Para Tourneur, The Last of the Mohicans también marcó un giro en su carrera. Bien puede ser considerada como la última producción importante del director y su última película norteamericana de alguna trascendencia real (pese a la continuación de Tourneur dirigiendo en los Estados Unidos hasta 1926). En vista de su importancia en la carrera de Tourneur, es una lástima que la dirección de The Last of the Mohicans pueda ser acreditada tanto a Brown como a Tourneur.

Brown proporcionó mucha información relativa a la filmación a Kevin Brownlow en su entrevista de septiembre de 1965 en París, gran parte de la cual continúa siendo inédita y otra sección fue publicada en The Parade's Gone By... Sobre la creación de Associated Producers, Inc., dijo:

Nuestra primera película fue THE LAST OF THE MOHICANS. Y no llevábamos en ella más que dos semanas cuando TOURNEUR saltó de un paralelo - se cayó- y estuvo en cama durante tres meses. Hice la película

${ }_{12}$ A los juicios de reconocidos historiadores que citamos en este trabajo, deben añadirse muchos otros. Ver también, por ejemplo: Everson, 1978, pp. 69, 151; Mitry, 1968, p. 286. 
completa después de eso. Todo. Él tuvo un accidente; estaba sobre un paralelo de 6 pies. Pudo haberse desarrollado en una pleuresía, pero sencillamente no podía salir de la cama. Por eso [la película] recayó sobre el pequeño Clarence, yo ya había hecho THE GREAT REDEEMER, sabes. (...) La hicimos en Yosemite Valley, donde los indios tenían la lucha sobre la roca (1965, p. 25).

A continuación, describió con todo detalle el calendario diario de rodaje y cómo se lograron algunos de sus efectos fotográficos más sobresalientes. La filmación comenzaba a las cuatro de la madrugada y se prolongaba hasta las diez de la mañana, momento en que se interrumpía. Después se retomaba a las tres del mediodía y duraba hasta las seis de la tarde: "Para entonces ya había aprendido a no rodar nunca exteriores entre las diez de la mañana y las tres de la tarde. La peor fotografía que puedes obtener es sobre el mediodía cuando el sol está cayendo directamente de pleno" (Brownlow, 1968, p. 142). Para crear la sensación de neblina entre los árboles utilizaron pucheros de humo; la lluvia torrencial en el bosque mediante un camión de bomberos y una manguera; y las nubes se consiguieron porque esperaron a que apareciesen y usaron filtros, ya que "Las nubes de normal no se registraban en la antigua película ortocromática" (Brownlow, 1968, p. 144). Y he aquí una de las primeras contradicciones que hallamos entre los que tomaron parte en el film, pues, como enseguida se comprobará, Charles J. van Enger indicó que en The Last of the Mohicans se empleó de modo invariable celuloide pancromático para los exteriores.

En la misma entrevista, Brown reveló detalles de cómo estuvo al mando de la película por completo. El presupuesto inicial era de 125.000-150.000 dólares, pero cuando se terminó los responsables de Associated Producers, Inc., se negaron a darle más dinero para continuar. Referente a la brutal y sobrecogedora escena de la caída de la heroína desde la roca (F2), relató:

Nos quedamos sin dinero. Esas escenas se tomaron todas en Y. [Yosemite] Valley que era lo último de la película [sic]. Y entonces los de Associated Producers - todos los directores que estaban en la compañía- vinieron a Universal y proyecté la película y les dije que quería finalizarla y que costaría alrededor de 25.00o dólares, y entonces y sólo entonces votaron para darme 
otros 25.000 dólares... y fui allí arriba e hice esas escenas en Y.V. (Brownlow, 1965, p. 25).

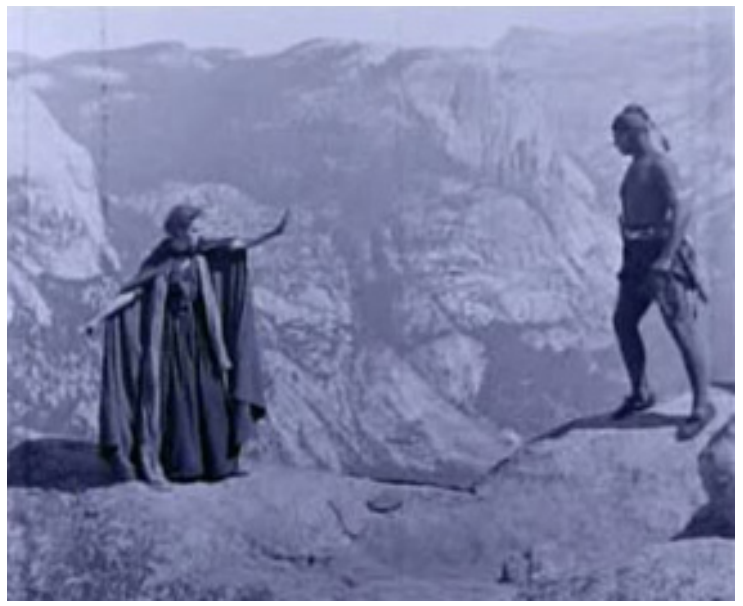

F2. Fotograma de la película filmado en Yosemite Valley, CA, correspondiente a la lucha y posterior muerte de la heroína.

El viaje de Brown a Yosemite, sin Tourneur, para filmar la escena, que en realidad es la penúltima, aparece corroborado por la prensa de la época. El 16 de octubre de 1920, Motion Picture News publicaba la siguiente información:

La compañía de Maurice Tourneur, que está filmando la historia de J. Fenimore Cooper "The Last of the Mohicans", está ahora en Yosemite Valley rodando exteriores. El Sr. Tourneur no hizo el viaje, pero envió a la compañía fuera con su ayudante, Clarence Brown. Entre los intérpretes que han hecho el viaje están Wallace Beery, Harry Woodward, Albert Roscoe, Barbara Bedford y Lillian Hall. La película estará finalizada a lo largo de las dos próximas semanas, según se ha anunciado (Jessen, 1920, p. 3038).

A pesar de lo apuntado por la publicación, Brown declaró que la toma de imágenes en Yosemite le llevó tres semanas (Brownlow \& Knox, 1969, p. 32). En entrevistas sucesivas, proporcionó declaraciones muy similares a las anteriores:

Tourneur estaba haciendo The Last of the Mohicans en ese momento. Él producía y yo era su ayudante. Pero se cayó de un andamio de madera cuando la película no llevaba más de dos semanas, y tuve que hacer la película prácticamente completa con él en el hospital. “¿Está esto bien, está esto bien?”, le preguntaba desde la cabecera de su cama (McGilligan \& Debra Weiner, 1975-1976, p. 31). 
Tan solo en una ocasión la memoria pareció fallarle y dijo que, aunque acometió la mayor parte de la filmación, rechazó que su nombre apareciera en los títulos de crédito:

...Tourneur, mientras rodaba The Last of the Mohicans se cayó de un andamio de madera y yo asumí el control por él. Hice alrededor de 3/4 partes de la película, pero no quise ningún crédito. Cuando se estrenó, fue el único éxito que tuvo Associated Exhibitors [sic] (Eyman, 1978, p. 20).

Había olvidado que el film se estrenó como co-dirigido por Maurice Tourneur y Clarence L. Brown, tal y como reseñan las crónicas contemporáneas (“The Screen”, 1921, p. 22). Pero su última acotación era del todo cierta, The Last of the Mohicans fue el único éxito financiero que conoció Associated Producers, Inc.

La versión de Brown aparece confirmada por su cámara Charles J. van Enger, quien constó acreditado por la fotografía junto a Philip R. DuBois. En una carta de 11 de agosto de 1972 a Richard Koszarski, apuntó:

En realidad Brown y yo hicimos un 90\% de la película. Hicimos todos los exteriores en Bear Valley y Yosemite. Mientras estábamos en Bear Valley, Tourneur rodó en el estudio una escena de masacre con un cámara desconocido. Cuando Tourneur quería acelerar la escena (accionábamos la cámara a mano) decía: "Lento con tu mano" y yo sabía lo que quería decir y aceleraba la acción. Este otro hombre no le entendía y aumentaba la velocidad y los indios parecían un grupo de bailarines de ballet. Antes de que dejáramos a Brulatour me pidió que hiciera una prueba con una película llamada pancromática, así que rodé todos los exteriores con ella. Era la primera producción hecha así. Las cuevas fueron rodadas en escenarios construidos en el estudio (Van Enger, 1988, pp. 41-43, 243-244).

$\mathrm{Al}$ año siguiente, Koszarski le entrevistó personalmente y volvió sobre el mismo tema. "¿Puede decirme algo sobre esa película? Tengo entendido que Tourneur cayó enfermo y no dirigió mucho de ella”. Y Van Enger contestó: "Bien, Tourneur era un tipo peculiar. Él hizo más o menos de director de la segunda unidad. Brown y yo hicimos la mayor parte de la película” (Koszarski, 1989, p. 279). 
Esta segunda vez aclaró que la escena de la cruel y voraz matanza de los indios al fuerte británico que Tourneur había filmado en Universal con otro cámara resultó inservible por culpa de este último, y Brown y él tuvieron que volver a rodarla de nuevo (Koszarski, 1989, pp. 279-280). Testimonio que vuelve a concordar con el de Brown, quien refirió cómo ideó la maquinaria necesaria para crear el travelling lateral subjetivo de la huida de las hermanas Munro de Fort William Henry: "Cuando las chicas se están escapando de la emboscada de los indios, puse la cámara en un cochecito. Lo construimos del eje de un Ford, con ruedas del Ford, una plataforma, y un asa para tirar de él calle abajo" (Brownlow, 1968, p. 144).

Realizamos un inciso para señalar un error en que Van Enger incurrió por omisión en su carta al historiador. Indicó que las cuevas se alzaron en el estudio, cuando en realidad las hubo de los dos tipos: recreadas en los sets de Universal, y cuevas móviles, erigidas en exteriores. Una fotografía de Clarence Brown en los momentos previos al rodaje en una de estas cuevas portátiles levantada en localizaciones da prueba de ello (F3). Kevin Brownlow, además, nos insistió en que forzosamente las cuevas tuvieron que estar ubicadas en ambos espacios, interiores y exteriores, ya que: "Ellos necesitaban el plano desde dentro mirando a la localización real, y después el plano desde fuera mirando dentro... que habría tenido que estar especialmente iluminado, o de lo contrario no se vería nada"13.

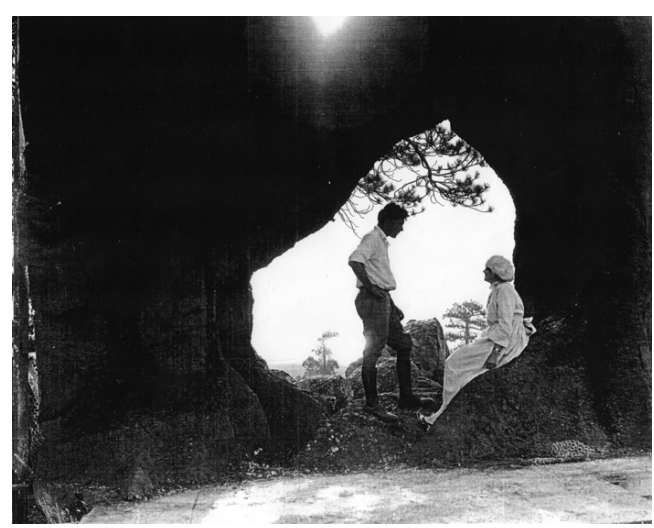

F3. Clarence Brown durante una pausa del rodaje en una de las cuevas portátiles erigida en exteriores

Un testimonio aparentemente divergente a los de Brown y Van Enger consta en el artículo pionero sobre Tourneur de George Geltzer (1961, p. 202):

${ }_{13}$ Correspondencia personal con Kevin Brownlow. 20/11/2008. 
La primera película de Tourneur para Associated Producers es probablemente su mejor película: The Last of the Mohicans. (...) Clarence Brown ha declarado que dirigió el 90 por ciento de esta película. Floyd Mueller, sin embargo, me dice que no cree que Brown lo hiciera.

Tras lo cual, adjuntaba el testimonio del director artístico Mueller, a quien entrevistó: "Él [Brown] dirigió gran parte de ella en el Big Bear Lake, pero creo que Tourneur dirigió prácticamente todas las escenas de estudio”. JanChristopher Horak (1977, p. 14), en su texto consagrado a la película, incluyó también las declaraciones de este último. No obstante, éstas, aun siendo idénticas en su contenido, por la forma en que están expuestas parecen distintas: "el director artístico de la película, Floyd Mueller, corrobora que Brown fue el responsable de todo el trabajo de localizaciones”.

Pero, en verdad, la explicación de Floyd Mueller no se diferencia tanto de la proporcionada por Charles J. van Enger, quien citaba a Tourneur dirigiendo escenas de interior en el estudio (aunque luego tuvieran que volver a filmarse). Asimismo, éste había declarado que Brown y él habían filmado el 90\% de The Last of the Mohicans, y, habida cuenta de la enorme proporción del film que transcurre en espacios abiertos, ambas versiones no son exactamente contradictorias.

En la entrevista filmada y no publicada que Kevin Brownlow y Donald Knox formularon a Clarence Brown en Hollywood en 1969, ambos historiadores intentaron averiguar qué partes había rodado cada uno de ellos, a lo que Brown contestó: "Si viéramos la película podría decirte casi escena por escena qué cosas [hice yo y qué cosas hizo Tourneur]... probablemente podríais decirlas vosotros mismos al ver las diferencias en la calidad del trabajo..." (Brownlow \& Knox, 1969, p. 32). “¿Cree que se perciben las diferencias?", le insistieron. "Bien, no sé de nadie que las notara, pero hay diferencias”, respondió. Tras lo cual, volvieron a preguntarle a propósito de la escena de la muerte de la heroína, cayendo despeñada desde lo alto de la roca: "Eso fue en Yosemite y yo hice todo eso". Y a la pregunta de qué rodó Tourneur durante las dos primeras semanas de rodaje, Brown especificó que se trató de la última escena del film, la del funeral, que se rodó la primera (F4) (Brownlow \& Knox, 1969, pp. 31-32). 


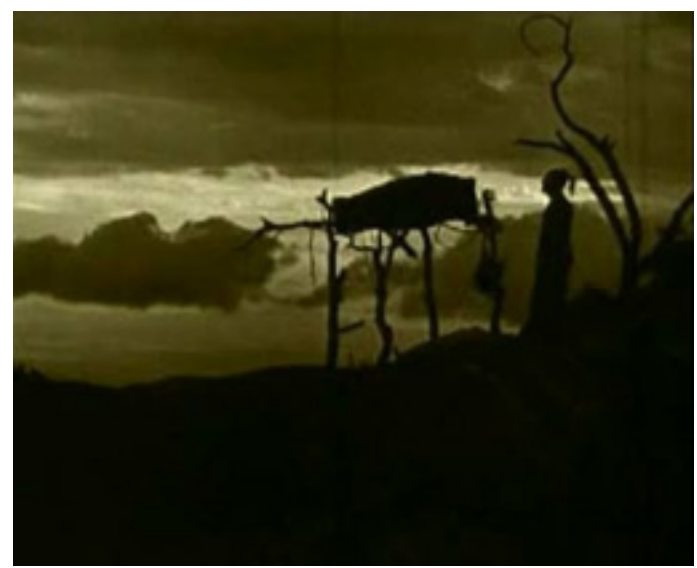

F4. Fotograma correspondiente a la escena del funeral, la última de la película.

Por todo lo expuesto, no es de extrañar que Richard Koszarski (1973, p. 27) se mostrara en extremo cauteloso cuando enunció: "Una comprensión de las relaciones entre Brown y Tourneur es crucial para cualquier juicio sobre The Last of the Mohicans (1921), generalmente considerada la mejor película de Tourneur".

En realidad, una información detallada sobre la relación de trabajo entre ambos había sido solicitada por el historiador a Charles J. van Enger, y éste le respondió de forma escueta, otorgando una gran simplicidad al asunto: "No había ningún procedimiento fijo en la asignación de la dirección entre Tourneur y Brown. Tourneur le decía a Brown qué era lo que quería y hacíamos el trabajo" (Van Enger, 1988, pp. 41-43, 243-244).

A raíz de su correspondencia y conversaciones con el cámara, Koszarski (1973, p. 27) de forma bastante acertada, y sin reducir la contribución de Brown a los exteriores, enunció: "Tourneur cayó de un andamio de madera al principio del rodaje y Brown dirigió la mayor parte de la película, aunque a través de las especificaciones diarias de Tourneur". El historiador no concedió tampoco mayor importancia a una fotografía de Tourneur que acababa de aparecer, donde se le veía totalmente sano preparando el maquillaje de los indios al aire libre ( $\left.\mathrm{F}_{5}\right)$ : "hay fotografías de un aparentemente saludable Tourneur en exteriores para esta película, pero la mayor parte del equipo de rodaje insiste en que él personalmente sólo dirigió los interiores, desde su silla de ruedas" (Koszarski, 1973, p. 27). Sin duda, Tourneur trabajó en localizaciones al comienzo de The Last of the Mohicans. 
De hecho, se lastimó en exteriores de Big Bear Lake y esta instantánea debió de ser tomada durante las primeras semanas de filmación.

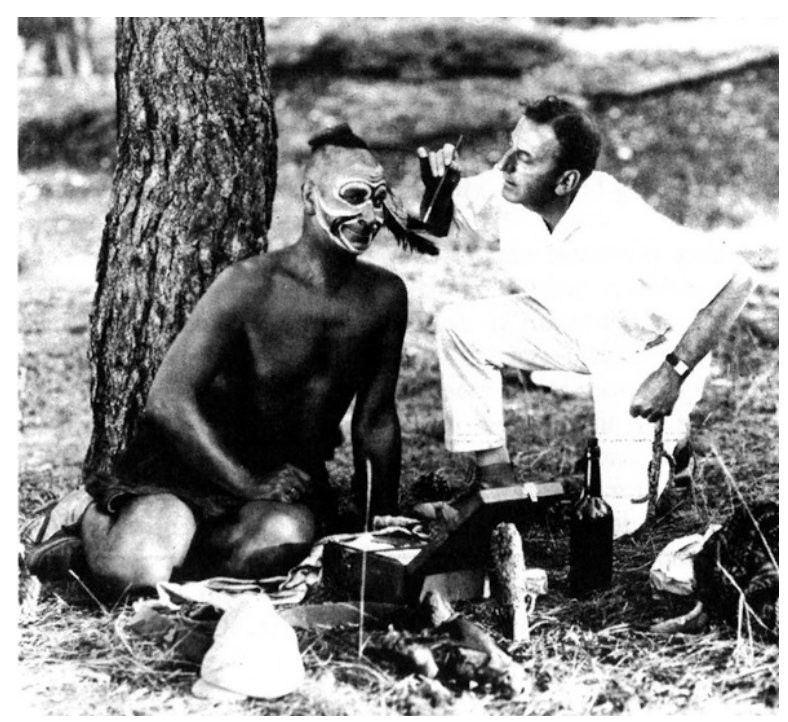

F5. Maurice Tourneur aplicando el maquillaje de los indios en exteriores.

Por otro lado, Brown nunca negó el trabajo de Tourneur en exteriores al inicio del rodaje. En 1939, en la primera parte de su autobiografía publicada por entregas en la revista británica Picturegoer, hizo alusión a la escena del funeral, aportando multitud de anécdotas sobre su filmación:

Un día Tourneur solicitó cien "Indios" extras para la escena del gran funeral, estando fuera en exteriores cerca de Lone Pine. Dorian no podía conseguirlos de Hollywood a tiempo. Por eso, a lo largo de la cima de la colina, en la distancia, colocó hileras de arbustos y maleza, engalanándolas con mantas indias y plumas para hacer de fondo. Tourneur diseñó la escena. "En este momento del funeral”, daba instrucciones, "tres hileras del primer término se retirarán. Después las siguientes tres hileras se moverán, a continuación se moverán los indios por la cima de la colina”. Dorian tartamudeaba y decía. "Pero, Sr. Tourneur”, objetaba, “¿va a mirar cuidadosamente a los indios de lo alto de la colina?” Tourneur entrecerró los ojos con cuidado. Finalmente tuvo la idea. Sin cambiar la expresión comentó: “iLos indios en la cima de la colina fuera del foco, no cambiarán de posición!” Tourneur era una alegría para todos nosotros (Brown, 1939, p. 7).

En The Classic American Novel \& the Movies, Jan-Christopher Horak publicó un texto sobre el largometraje, que tituló como sigue: “The Last of the Mohicans (1826), James Fenimore Cooper: Maurice Tourneur's Tragic Romance”. Es decir, sin mención alguna al nombre de Brown y sin ningún 
tipo de indicación de que se trató de una película co-dirigida. En su estudio, la participación de Brown quedaba reducida a una nota al pie, donde curiosamente señaló: "La cuestión histórica relativa a la autoría de la película y la relación existente entre los co-directores Toumeur y Brown debe resolverse. Brown, aunque siempre ha reconocido su deuda con Toumeur, generalmente ha reivindicado mucho crédito de la película” (Horak, 1977, pp. 12, 14). Tras lo cual, indicó: "Pero es de suponer que Toumeur, como productor-director que insistía en mantener el control total, revisaba diariamente los copiones de Brown y le daba órdenes para el rodaje del día siguiente" (Horak, 1977, p. 14).

Efectivamente, Brown siempre expresó su gratitud hacia Tourneur y reconoció su autoridad al frente del largometraje. Es más, llegó incluso a decir: "Tourneur vio todos los copiones. Él podía ser muy categórico. La primera pedorreta que escuché vino de Maurice Tourneur $-\mathrm{y}$ cuando la escuché, sabía que significaba repetir la toma” (Brownlow, 1968, p. 144). Sin embargo, si Tourneur permaneció seis semanas completas en el hospital difícilmente pudo ver todos los copiones - al menos no de forma simultánea a cómo se rodaban; es de suponer que los vio a posteriori.

Para Horak, el estilo visual de la película es típico de Tourneur, antes y después de Mohicans, razón por la que suprimió a voluntad a Brown como co-director. Pero la estética pictorialista de Tourneur fue, y estaba ya en esta época, intensamente asimilada por Brown, tal y como demostraremos en el epígrafe 5 .

Finalmente, en American Directors se incluyó uno de los pocos análisis sobre el film donde el objeto de estudio era Brown, el cual, como era de esperar, presenta una opinión contraria a la de Horak y mayoría de historiadores precedentes. Debido a Barry Gillam (1983, p. 29), dice así:

Uno puede considerar el éxito de The Last of the Mohicans en buena parte como el resultado del trabajo de Brown en el plató con los actores, ritmo y puesta en escena y creación de tensión, drama, estado de ánimo -el juego de las emociones. Plano por plano es una película diseñada por Tourneur, pero en lugar de las imágenes estáticas del maestro, las de Brown son... más "dinámicas". 


\subsection{Recepción crítica y autoría en la época del estreno}

The Last of the Mohicans se estrenó el 21 de noviembre de 1920, constituyendo un gran triunfo de público y de crítica. Tourneur recibió los enaltecimientos más grandes de su carrera y los más importantes desde sus films de vanguardia de 1918 (también serían los últimos). Motion Picture News escribió con relación a Tourneur: "No puede discutirse que es su mayor logro, una película de la que se hablará como una obra maestra de su clase...” (Reid, 1920, p. 4343). El New York Times la calificó de "película excepcional":

En lo que al Sr. Tourneur respecta ha utilizado la magia de su cámara para dar a la historia de Cooper la calidad de la vida en la pantalla. (...) no fotografió simplemente su escenario y personajes de manera literal. Compuso sus cuadros. Con luces y sombras colocadas de forma hábil, objetos artísticamente situados, distancias efectivamente medidas, puso dentro de su película más de lo que cualquiera habría observado de la realidad ante su cámara (“The Screen”, 1921, p. 22).

Los elogios hacia The Last of the Mohicans y Maurice Tourneur continuaron a lo largo de 1921. Un fuerte tributo vino de parte de Robert E. Sherwood, desde Life:

Desearíamos que a todos aquéllos a los que les encanta burlarse de las películas pudiera obligárseles por acta del Congreso a ver la producción de Maurice Tourneur, The Last of the Mohicans. Estarían bajo lo que por lo general se conoce como un rudo despertar. Porque aquí hay una película que combina una belleza pictórica magnífica con auténtico poder dramático que puede mantener la atención del espectador sin insultar su inteligencia... (Sherwood, 1921, p. 177).

Ésta fue la tónica general: a Clarence Brown ni siquiera se le mencionó en las reseñas.

\section{Estética fílmica del largometraje y autoría}

Antes de proceder al estudio plástico del film, es oportuno registrar que el largometraje original estadounidense no se conserva y lo que nos ha llegado es una copia que estuvo destinada a la exhibición comercial en Francia. 
De hecho, The Last of the Mohicans fue una película perdida hasta 1957, cuando James Card, conservador de George Eastman House/International Museum of Photography and Film, Rochester, Nueva York, descubrió un negativo original de nitrato de $35 \mathrm{~mm}$ en la Cinémathèque Française de París ${ }^{14}$. Como en el caso de la gran mayoría de films norteamericanos hallados en el extranjero, este negativo, con rótulos en francés, consistía en una copia de seguridad o segunda copia de la película, ensamblada a partir de tomas reserva y descartes del original, y no contenía las interpretaciones finales de los actores ni las tomas consideradas por Tourneur y Brown como definitivas ${ }^{15}$.

En consecuencia, las imágenes que componen el film deben ser entendidas a modo de "bosquejo" o "borrador". Pese a todo, son las únicas que existen para llevar a cabo el análisis. Éstas despliegan todos los particulares de la estética fílmica pictorialista de Tourneur, sintetizada en una serie de recursos que se repiten una y otra vez en sus películas. Uno de los más relevantes es el arco o cueva.

Desde sus primeras películas norteamericanas, Tourneur con frecuencia dispuso sus escenas mediante el uso de máscaras superpuestas sobre la imagen con forma de arco -cfr. The Blue Bird (F6). Este módulo tan artificioso y ostensible, con el que al mismo tiempo creaba otra de sus soluciones habituales - el primer término oscuro-, respondía a diversos propósitos de índole narrativa y estética. Desde el punto de vista de la dramaturgia fílmica, el arco se superpone entre el público y la acción de la película y actúa a modo de barrera y expulsión del espectador del universo narrativo del film, subrayando el carácter de ficción de lo que sucede en la

14 Desde que en 1949 James Card ocupó el puesto de preservador del Museo, inició una intensa búsqueda de películas pérdidas, llegando a conseguir para George Eastman House una colección que, con 25.00o títulos, se sitúa hoy como el mayor archivo cinematográfico del país después de la Library of Congress (LOC). Su amistad con Henri Langlois, entonces director de la Cinémathèque, permitió la recuperación y repatriación de muchos títulos silentes norteamericanos a los Estados Unidos.

15 Repatriado a Norteamérica, George Eastman House llevó a cabo su preservación procediendo a la generación de un nuevo negativo original de $35 \mathrm{~mm}$ en soporte de acetato, para el que se crearon nuevos rótulos en inglés. La película fue restaurada en 1993 por JanChristopher Horak, quien diseñó una nueva paleta cromática, basándose en tinciones y tonalidades habituales del periodo. En 2000 se editó una excelente versión en DVD por Lumivision Corporation en asociación con el Museo. La versión española de DVD de Classicmedia se deriva de esta última. 
acción. Mientras que desde una perspectiva plástica, enmarca las escenas, ejerciendo de reencuadre dentro del encuadre y reasentando a los personajes dentro del plano. Para Richard Koszarski (1973, p. 26), el origen del mismo en la obra de Tourneur se localiza en sus experiencias previas en la escena francesa y, concretamente, lo consideró un derivado del arco del proscenio teatral, que sitúa directamente al espectador en un patio de butacas de un teatro figurado. Mientras que Kevin Brownlow (1979-1980, p. 50) lo asimiló con las superficies arquitectónicas de la obra del pintor simbolista Puvis de Chavannes, con el que Tourneur trabajó en la decoración mural de la escalera de la Boston Public Library, Boston, Massachusetts. Ciertamente, ambas argumentaciones son posibles y no excluyentes.
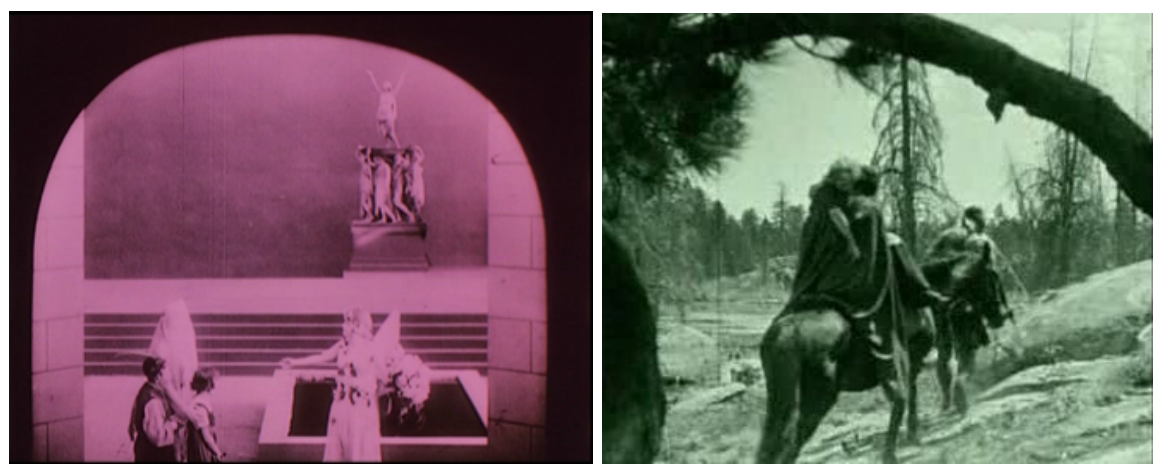

F6. The Blue Bird (Tourneur, 1918). F7. The Last of the Mohicans (Tourneur \& Brown, 1920).

Desde que el uso de máscaras y mecanismos ópticos superpuestos sobre la imagen comenzaron a caer en desuso en los preludios de 1920, Tourneur hizo evolucionar sus superficies de arco - figuradas o reales- camuflándolas bajo las más diversas estructuras, sobre todo por medio de la naturaleza adoptando dicha forma y grutas o cuevas - The Last of the Mohicans presenta ambos tipos de representación del arco (F7 y F8). Asimismo, las tiendas de los indios poseen idéntica función (F9). La cueva se repite hasta tal extremo de ocasiones que se instaura, sin duda, como el elemento iconográfico emblemático del film. Dichos dispositivos figuran de manera casi exacta en la obra en solitario de Clarence Brown. Generalmente, éste enmascaró el arco del proscenio a través de troncos y ramas de árboles National Velvet (1944) (F10) - y de cortinas laterales diegéticas, dispuestas en uno o en ambos lados de la pantalla - The Light in the Dark (1922) (F11). Es más, Brown llegó a utilizar las máscaras negras con forma de arco 
estrictamente como tales en films de mediados de los años 20, cuando eran totalmente anacrónicas -The Eagle (El águila negra, 1925), Flesh and the Devil (El demonio y la carne, 1926)-, e incluso en películas sonoras - The Rains Came (Vinieron las lluvias, 1939) (F12).

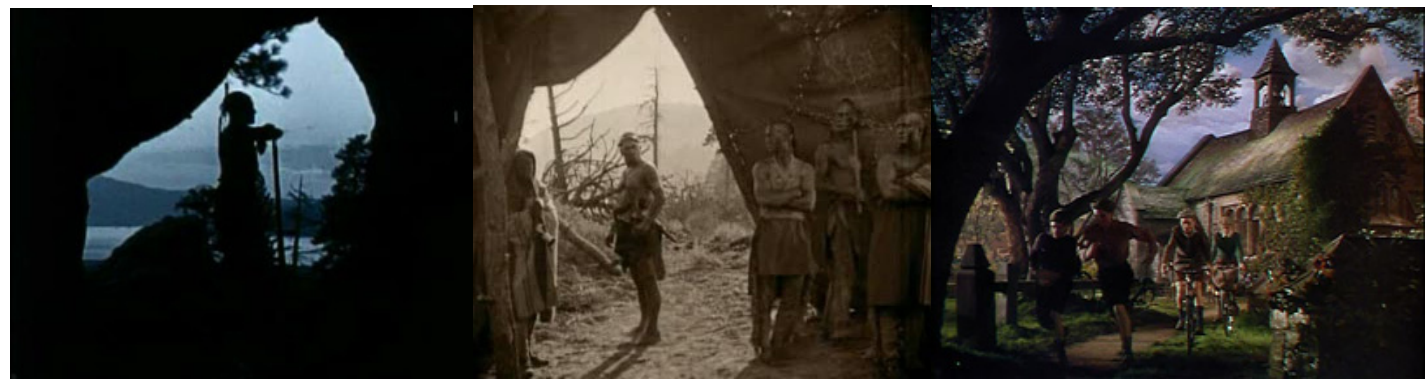

F8. The Last of the Mohicans (Tourneur \& Brown, 1920). F9. The Last of the Mohicans (Tourneur \& Brown, 1920). F10. National Velvet (Brown, 1944).

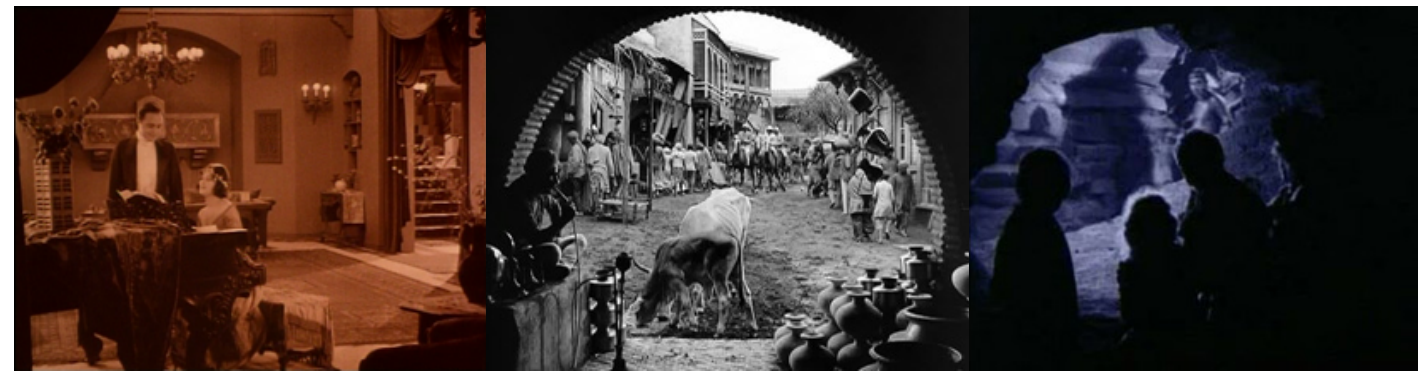

F11. The Light in the Dark (Brown, 1922). F12. The Rains Came (Brown, 1939). F13. The Last of the Mohicans (Tourneur \& Brown, 1920).

De igual forma, los diseños de primer término oscuro y las siluetas a contraluz son valores plásticos de Tourneur que se dan cita en The Last of the Mohicans (F13), y ambos figuran de modo permanente en la obra fílmica posterior de su discípulo -Flesh and the Devil (F14).
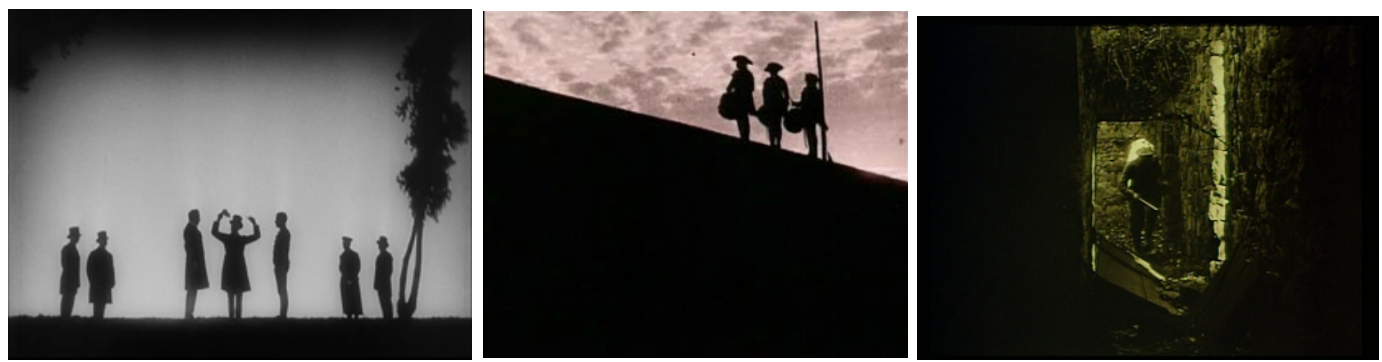

F14. Flesh and the Devil (Brown, 1926). F15. The Last of the Mohicans (Tourneur \& Brown, 1920). F16. The Light in the Dark (Brown, 1922).

Las unidades geométricas en negro que bloquean y delimitan la pantalla se establecen como otro rasgo específico del estilo de Tourneur, muy acusado en Mohicans (F15), que igualmente se localiza en el corpus fílmico de Brown The Light in the Dark (1949) (F16). 
Finalmente, la disposición circular de los personajes en torno a la lumbre de un fuego diegético -influencia del pintor George de La Tour- es otra marca propia de Tourneur (F17). Y en la obra de Brown abundan las escenas de personajes llevando candiles en medio de la noche o irradiados desde dentro del encuadre por fuentes de luz diegéticas de la más diversa índole - fuegos, cirios, faros de coches, linternas, lámparas eléctricas incandescentes, etc. Anna Karénina (Ana Karenina, 1935) (F18).
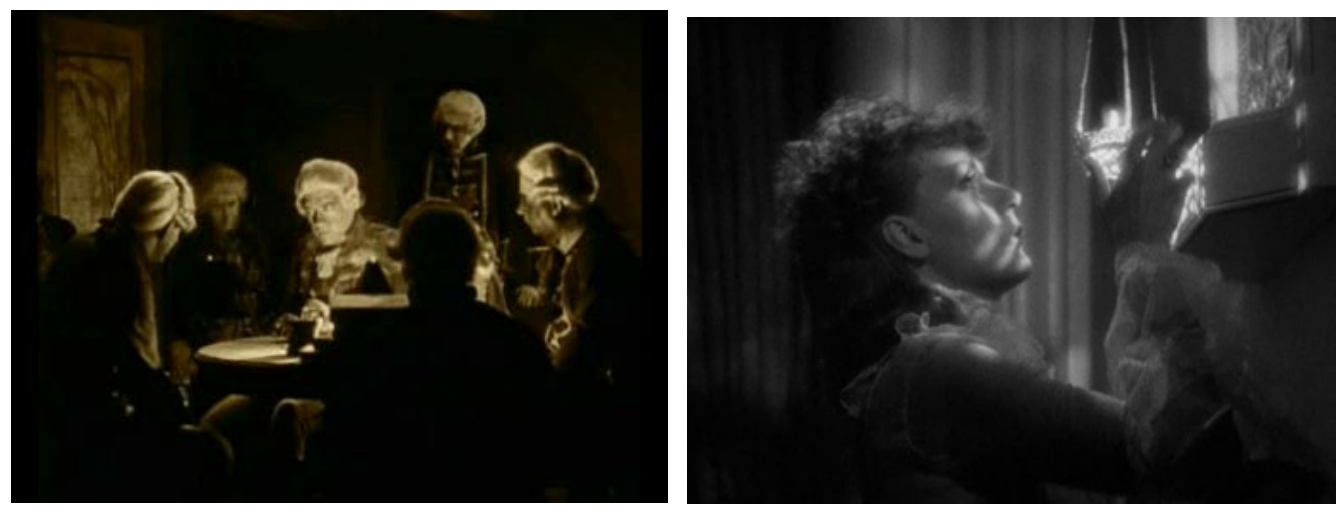

F17. The Last of the Mohicans (Tourneur \& Brown, 1920). F18. Anna Karénina (Brown, 1935).

Ahora bien, si los elementos mencionados sobre estas líneas remiten al estilo de Tourneur, que Brown absorbió, y apuntarían hacia el diseño y planificación de la película por parte del director francés, esta posibilidad se desdibuja desde el momento que The Last of the Mohicans ostenta abundantes rasgos que son estrictamente exclusivos de Clarence Brown.

El más importante es el "plano de tres", de los cuales Mohicans exhibe nada menos que trece (F19 y F20). Ésta es una es una agrupación de personajes absolutamente privativa de Brown, con la que estableció su rubrica plástica personal, firmando con ella buena parte de su filmografía, tanto silente como sonora, a menudo colocándola al término de las secuencias -Sadie McKee (Así ama la mujer, 1934)-, de la historia dramática - The Light in the Dark, The Signal Tower (La caseta de señales, 1924) - o del film -Smouldering Fires (La llama del amor, 1925), The Goose Woman (La mujer de los gansos, 1925) (F21). 

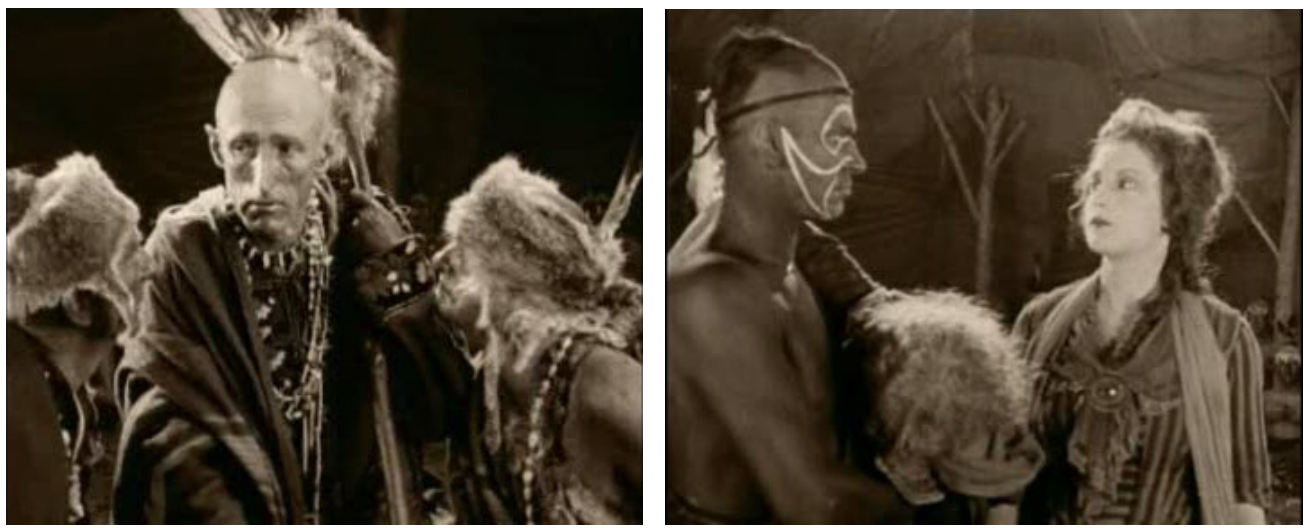

F19. The Last of the Mohicans (Tourneur \& Brown, 1920). F20. The Last of the Mohicans (Tourneur \& Brown, 1920).
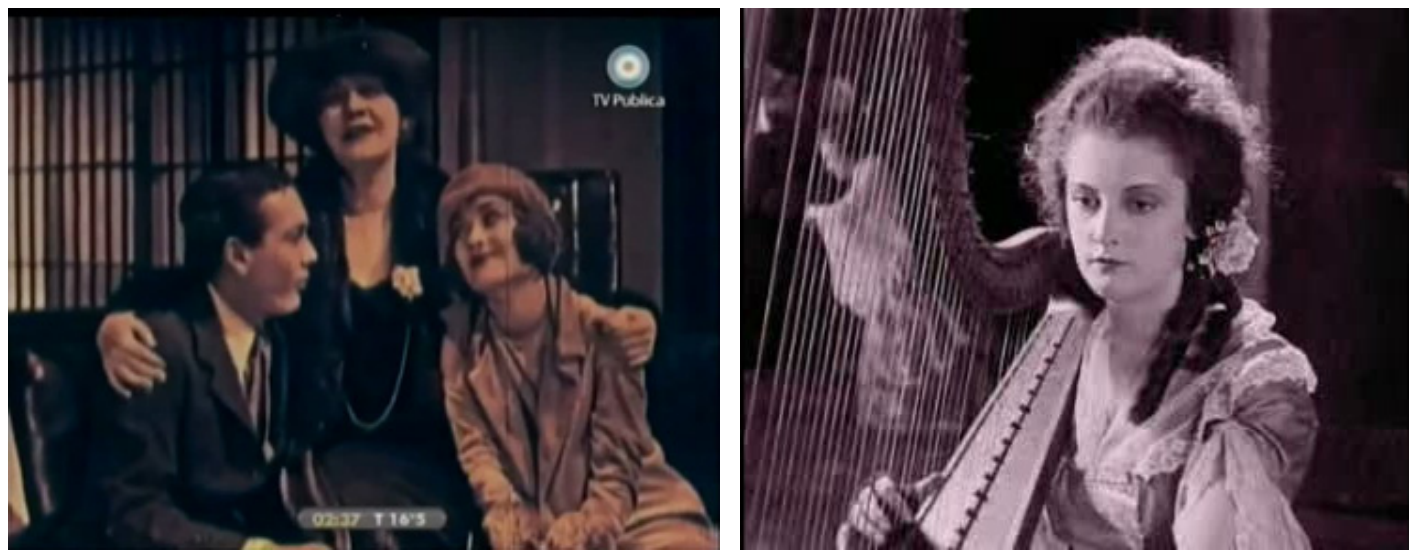

F21. The Goose Woman (Brown, 1925). F22. The Last of the Mohicans (Tourneur \& Brown, 1920).

Los "planos de tres” de Brown poseen parámetros muy codificados, entre los que cabe registrar: 1.) Cualidades plásticas de centrado, simetría, equilibrio y proporción. 2.) Frontalidad del encuadre y de los personajes. 3.) Las figuras se disponen formando triángulos o pirámides invertidas. 4.) Inmovilidad total o parcial de los integrantes. 5.) Son planos detenidos, que se mantienen en la pantalla durante tiempo considerable. 6.) Poseen significado simbólico y narrativo, dado que ponen de relieve los conflictos internos de los implicados y el director muchas veces los utilizó para plasmar problemas de triángulos amorosos. 7.) En ellos se producen sucesivos cruces de miradas y distintos gestos. 8.) Al concluir los segmentos o el film, tras ellos suele constar un signo de transición óptica, generalmente un fundido en negro. 9.) En ocasiones, además, encierran el clímax. 

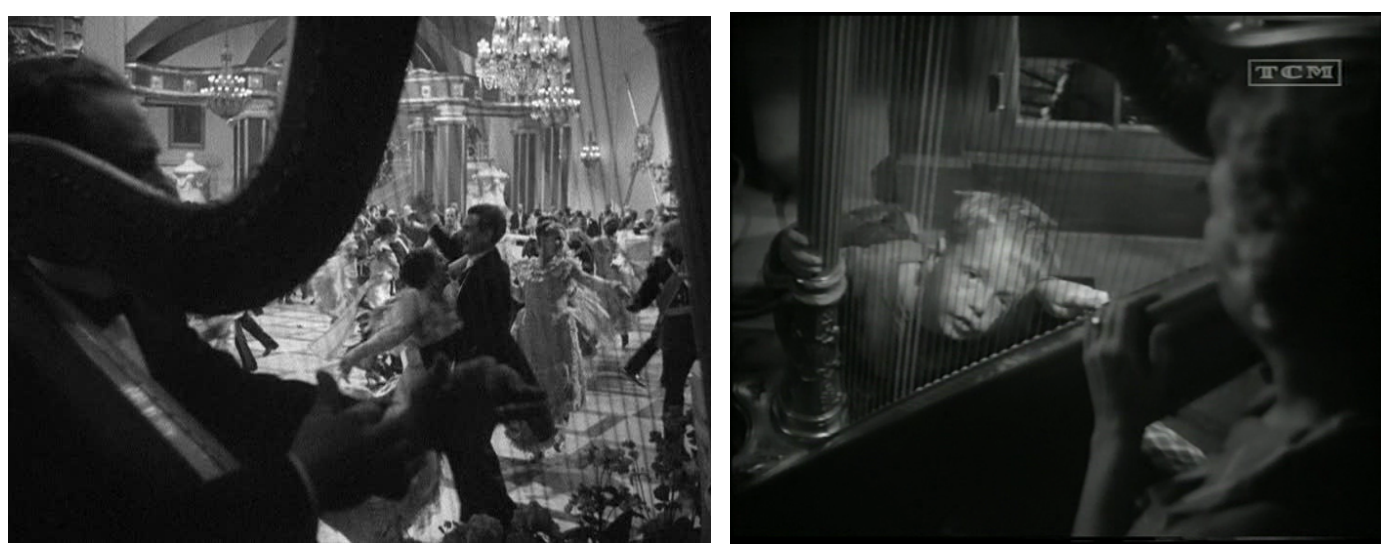

F 23. Anna Karénina (Brown, 1935). F24. The Human Comedy (Brown, 1943).

The Last of the Mohicans incluye muchas otras fórmulas y soluciones visuales que tan sólo pueden encontrarse en la producción de Brown. Sirva como ejemplo el plano de la heroína, Cora, tocando el arpa, donde la fotografía con profundidad de campo permite distinguir a través de las cuerdas del instrumento una acción que se desarrolla en el segundo término (F22). Se trata de una escena de interior y, por tanto, en teoría, filmada por Tourneur. Pero planos muy similares se repiten en los films de Brown Anna Karénina (F23) y The Human Comedy (F24).

\section{Conclusiones}

Los testimonios de los que intervinieron en The Last of the Mohicans Clarence Brown, el cámara Charles J. van Enger y otros miembros del equipo entrevistados por Richard Koszarski- no dejan lugar al equívoco: Brown acometió la mayor parte del film. Además, una porción sustancial de esta información - las tres semanas de Brown rodando en Yosemite Valley con la película totalmente a su cargo- aparece confirmada por datos históricos publicados en la época del rodaje por revistas de cine especializadas.

Con todo, nuestro análisis ha revelado que existe una imposibilidad bastante obvia de atribuir escenas concretas y determinadas a cualquiera de los codirectores; inviabilidad que encuentra su razón de ser en la completa asunción de Brown de las técnicas de Tourneur. Dicho de otro modo, Brown había asimilado hasta tal extremo la estética de su maestro que resulta imposible discernir qué partes rodó cada uno de ellos. De hecho, las 
declaraciones de los que participaron en el largometraje tan solo permiten la atribución de tres escenas en particular: el travelling lateral subjetivo de las hermanas Munro escapando del fuerte durante el asedio de los indios, perpetrado por Brown; la muerte de Cora cayendo desde la roca, asimismo realizado por Brown; y la escena final del funeral, filmada por Tourneur. Todo lo demás se adentraría en el terreno de la especulación. Por ejemplo, las imágenes de Cora tocando el arpa en un interior, que a priori podrían apuntar hacia la autoría de Tourneur, remiten al corpus fílmico posterior de Clarence Brown. En realidad, y pese a lo expuesto, cualquiera de los dos pudo haber rodado esos planos.

En cuanto a la historiografía, como se ha podido observar la inclinación en la balanza de la autoría es bien distinta dependiendo de cada historiador. Y así, con la notable excepción de Koszarski, a los especializados en Tourneur o que han estudiado con mayor detenimiento su trayectoria la figura de Brown como co-director les resulta sumamente incómoda -Slide- o han tendido a minimizar su contribución, reduciéndola en el mejor de los casos al rodaje de exteriores -Geltzer. El caso más extremo de esta corriente historiográfica, que ha sido la predominante a lo largo de las décadas, lo presentó el prestigioso investigador y preservador Jan-Christopher Horak, quien en su estudio del largometraje eliminó por completo la contribución de Brown como co-director, relegándole a una nota al pie.

Por otro lado, incluso los analistas más imparciales o favorables a reconocer la importante aportación de Brown han sostenido un mismo dictamen, que consta de forma subyacente en todos los artículos examinados: la película fue planificada por Tourneur, pero ejecutada -en mayor o menor medida (esto ya varía dependiendo del autor)- por Brown.

Sin embargo, reducir la función de Brown a las labores de mero ejecutor a las órdenes de Tourneur, como si no hubiera aportado ideas propias al largometraje, es un error, algo que, pensamos, también ha quedado demostrado a través de nuestro análisis, donde su huella -especialmente palpable en los "planos de tres" y en los movimientos de cámara con maquinaria de fabricación propia (él había sido ingeniero y siguió confeccionando artefactos similares y más complejos durante toda su 
carrera) - es incontestable. Otros aspectos que por una cuestión de espacio no han podido desarrollarse, tales como el ritmo narrativo dinámico de la cinta y la cálida aproximación a la dirección de actores, apuntarían igualmente hacia las competencias de Brown.

De hecho, su trabajo en The Last of the Mohicans fue tan brillante que Tourneur no sólo le concedió la mitad del crédito de la película, sino que lo convirtió en su co-director oficial en la siguiente: The Foolish Matrons. Este segundo film fracasó en el box-office y después Brown se separó de su mentor e inició su andadura en solitario.

A partir de ese momento, la carrera de Tourneur comenzó a caer en picado. El cineasta no volvió a realizar nunca, ni en los Estados Unidos ni en su Francia natal, a donde en 1926 regresó, una película de éxito mayoritario. The Last of the Mohicans fue su última gran producción y al mismo tiempo, con toda probabilidad, su mejor contribución al cine norteamericano.

Por contraposición, tras separarse de su maestro Brown se embarcó en una triunfante y longeva trayectoria en Hollywood que se prolongó hasta 1953. Dirigió a Rudolph Valentino en la que está considerada por muchos su mejor película - The Eagle -, a Greta Garbo en más ocasiones que cualquier otro siete en total-, incluyendo Flesh and the Devil y Anna Karénina, y en su filmografía pueden encontrarse "clásicos" de la historia del cine como National Velvet, el film que convirtió en estrella a Elizabeth Taylor, y The Yearling (El despertar, 1946).

Y esto explica la inversión de los nombres de ambos directores efectuada por Classicmedia en la carátula de la edición de DVD. Se patentiza así que, si bien ambos cineastas lamentablemente están olvidados en el presente, la figura de Maurice Tourneur lo está aún más que la de su discípulo.

\section{Referencias bibliográficas}

Bordwell, D., Staiger, J. \& Thompson, K. (1997). El cine clásico de Hollywood. Estilo cinematográfico y modo de producción hasta 1960. Barcelona: Paidós.

Brown, C. (6 de mayo de 1939). 50 Million Feet of Hollywood Romance 
(Begin Clarence Brown's Film Story). Picturegoer, 8 (415), pp. 6-7.

Brownlow, K. (1965, septiembre). Entrevista no publicada a Clarence Brown en París. Material inédito en The Kevin Brownlow Collection, Londres, Reino Unido. Transcripción desde soporte electromagnético proporcionada por el autor.

Brownlow, K. (1966, octubre). Entrevista no publicada a Clarence Brown en París. Material inédito en The Kevin Brownlow Collection, Londres, Reino Unido. Transcripción desde soporte electromagnético proporcionada por el autor.

Brownlow, K. (1968). Clarence Brown. En The Parade's Gone By... Berkeley: University of California Press, pp. 136-153.

Brownlow, K. (1979-1980). Ben Carré. Sight \& Sound, 49 (1), (invierno), pp. 46-50.

Brownlow, K. \& Knox, D. (1969). Entrevista filmada no publicada a Clarence Brown en Hollywood. Material inédito en The Kevin Brownlow Collection, Londres, Reino Unido. Transcripción desde celuloide proporcionada por el autor.

Crawford, H. (1964). Clarence Brown: Hollywood Great, Desert Pioneer. Palm Springs Life, (enero), 10-14, 16-17. Documento por cortesía de The Clarence Brown Collection, Special Collections Library, The University of Tennessee, Knoxville, Tennessee, USA.

Everson, W. K. (1978). American Silent Film. Nueva York: Oxford University Press.

Eyman, S. (1978). Clarence Brown: Garbo and Beyond. Velvet Light Trap, 18, (primavera), pp. 19-23.

Garnett, T. (1996). Clarence Brown. En Directing: Learn from the Masters, "The Scarecrow Filmmakers Series", no 48. Lanham y Londres: Scarecrow Press, pp. 12-20.

Geltzer, G. (1961). Maurice Tourneur. Films in Review, 12 (4), (abril), pp. 193-214.

Gilbert, J. (1928). Jack Gilbert Writes His Own Story. Photoplay, 34 (4), (septiembre), pp. 41-43, 101-106.

Gillam. B. (1983). Clarence Brown. En J-P. Coursodon \& P. Sauvage (Eds.), American Directors, Vol. 1 (2 Vols.). Nueva York: McGraw-Hill Book Company, pp. 26-36..

Horak, J-C. (1977). The Last of the Mohicans (1826), James Fenimore Cooper: Maurice Tourneur's Tragic Romance. En G. Peary \& R. Shatzkin (Eds.), The Classic American Novel \& the Movies. Nueva York: Frederick Ungar, pp. 10-19.

Jessen, J. C. (16 de octubre de 1920). Production on the West Coast Associated Producers. Motion Picture News, 22 (17), p. 3038.

Koszarski, R. (1973). Maurice Tourneur. The First of the Visual Stylists. Film Comment, 9 (2), (marzo-abril), pp. 24-31.

Koszarski, R. (1989). Career in Shadows: Interview with Charles Van Enger. Film History, 3 (3), pp. 275-290.

Koszarski, R. (2004). Fort Lee: The Film Town. Roma: John Libbey.

Maurice Tourneur (28 de noviembre de 1914). Moving Picture World, 22 (9), p. 1242. 
McGilligan, P. \& Weiner, D. (1975-1976). Clarence Brown at 85. Focus on Film, 23, (invierno), pp. 30-33.

Miss Clark to Star in "Prunella" (19 de enero de 1918). Moving Picture World, 35 (3), p. 396.

Mitry, J. (1968). Maurice Tourneur, “Anthologie du Cinéma”, no 36. París: Anthologie du Cinéma.

Neely, J. (6 de marzo de 2008). The Forgotten Director: Who was Clarence Brown? - Tracing the Footsteps of One of the Most Succesful Filmmakers of Hollywood's Golden Age, at Home. Metro Pulse. Knoxville's Weekly Voice, 18 (10), pp. 16-23.

Reid, L. (4 de diciembre de 1920). The Last of the Mohicans. Motion Picture News, 22 (24), p. 4343.

Sherwood, R. E. (3 de febrero de 1921). The Last of the Mohicans. Life, 177.

Slide, A. (1982). The Last of the Mohicans. En F. N. Magill (Ed.), Magills Survey of Cinema: Silent Films, Vol. 2 (3 Vols.). Englewood Cliffs: Salem Press, pp. 650-653.

Tavernier, B. \& Coursodon, J-P. (1997). Clarence Brown. En 50 Años de Cine Norteamericano, Vol. 1 (2 Vols.). Madrid: Akal, pp. 370-377.

The Screen (3 de enero de 1921). New York Times, p. 22.

Tourneur's "Woman" at Rivoli a Departure from the Usual (9 de noviembre de 1918). New York Dramatic Mirror, 79 (2081), p. 700.

Tourneur to Produce Films in California (9 de noviembre de 1918). New York Dramatic Mirror, 79 (2081), p. 701.

Tourneur Ill with [ptomaine] Poisoning (23 de octubre de 1920). Moving Picture World. P. 1134.

Van Enger, C. J. (1988). Una lettera di Charles J. van Enger/A letter from Charles J. Van Enger. Griffithiana, 32-33, (septiembre), pp. 41-43, 243-244.

Cómo citar: Guiralt Gomar, C. (2015). “Aportaciones historiográficas y estéticas a propósito de la co-autoría fílmica de The Last of the Mohicans (1920), de Maurice Tourneur y Clarence L. Brown". Fotocinema. Revista científica de cine $y$ fotografia, 11, pp. 50-81. Disponible: http://www.revistafotocinema.com/ 